\title{
SE OF A WHOOPING CRANE NEST BY SANDHILL CRANE
}

NIE KUYT, Canadian Wildlife Service, Room 210, 4999 - 98 Avenue, honton, Alberta. T6B 2X3

ach spring the Canadian Wildlife vice (CWS) surveys the Whooping he breeding range in Wood Buffalo ional Park (WBNP) to determine inion of nest building and egg laying Whooping Cranes as well as location number of nests, clutch size and itification of nesting and non-nestbirds based on individually diagnoscolour bands. ${ }^{8}$ Most of the work is al in nature, and is carried out by ans of surveys in small fixed-wing raft, based in Fort Smith, Northwest itories. $^{6}$

uring the removal of surplus eggs in May, nests, nest ponds and eggs are mined. ${ }^{4}$ A Bell 206 helicopter is during these visits, the only times pring when observers are on the ind. The pilot lands the helicopter close to the nest as convenient lout dislodging nesting material by rotor wash. Duration of nest visits e from landing of helicopter to takedepends on the type of helicopter ercarriage (pontoons are best and skids better than low ones), skill experience of the pilot in handling machine and in selecting landing and on the difficulty of the terrain egg collectors must traverse be n helicopter and nest. Nest visits 82) during egg pickup from 1986 3 varied from $3-20 \mathrm{~min}$. per nest the mean nest visit lasted $8.5 \mathrm{~min}$. ng this time, one or two observers or wade from the helicopter to the photograph the nest, record nest ensions and water depth of nest 1 , test viability of one or both eggs e nest, collect one egg and return e helicopter. The viability test in- volves briefly immersing the egg in a container of $30-34^{\circ} \mathrm{C}$ water and watching for movements of the egg in still water. Egg removals since 1985 have taken place between 21 and 27 May and, as most eggs are then about 24 days old (incubation period of $29-30$ days), the embryo is large and its movements within the shell cause the egg to rotate or rock. The live egg selected to remain is carefully blotted dry and replaced in the nest. Sometimes the second egg is also tested at the nest in case substitution of a live egg into a nest containing non-viable eggs has to be made. The result of this nest management is that a maximum of viable single egg clutches is being incubated by Whooping Cranes. Since 1985, the technique has resulted in a $12-16 \%$ increase in hatching success of single egg clutches left in WBNP and undoubtedly has enhanced production of juvenile birds.

On 8 May 1988 nest $21 / 88$ was found in the northwest corner of the "nonbreeder" area between Sass and Klewi rivers. ${ }^{5}$ One of the two adults attending the nest was colour-banded on 13 August 1979 as an unfledged chick in the Klewi marshes about $10 \mathrm{~km}$ northeast of the location of nest $21 / 88$. That bird, banded BWB-Red was found with an unbanded bird at its first nest (26/84) in May 1984 about $2.6 \mathrm{~km}$ northeast of present nest $21 / 88^{\circ}$ The two cranes produced two eggs in 1984 and the chick, hatched from the egg left in the nest after the 1984 egg pickup was banded (White-Blue) in August 1984. That fall, the unbanded adult apparently collided with a power line near Lin- 


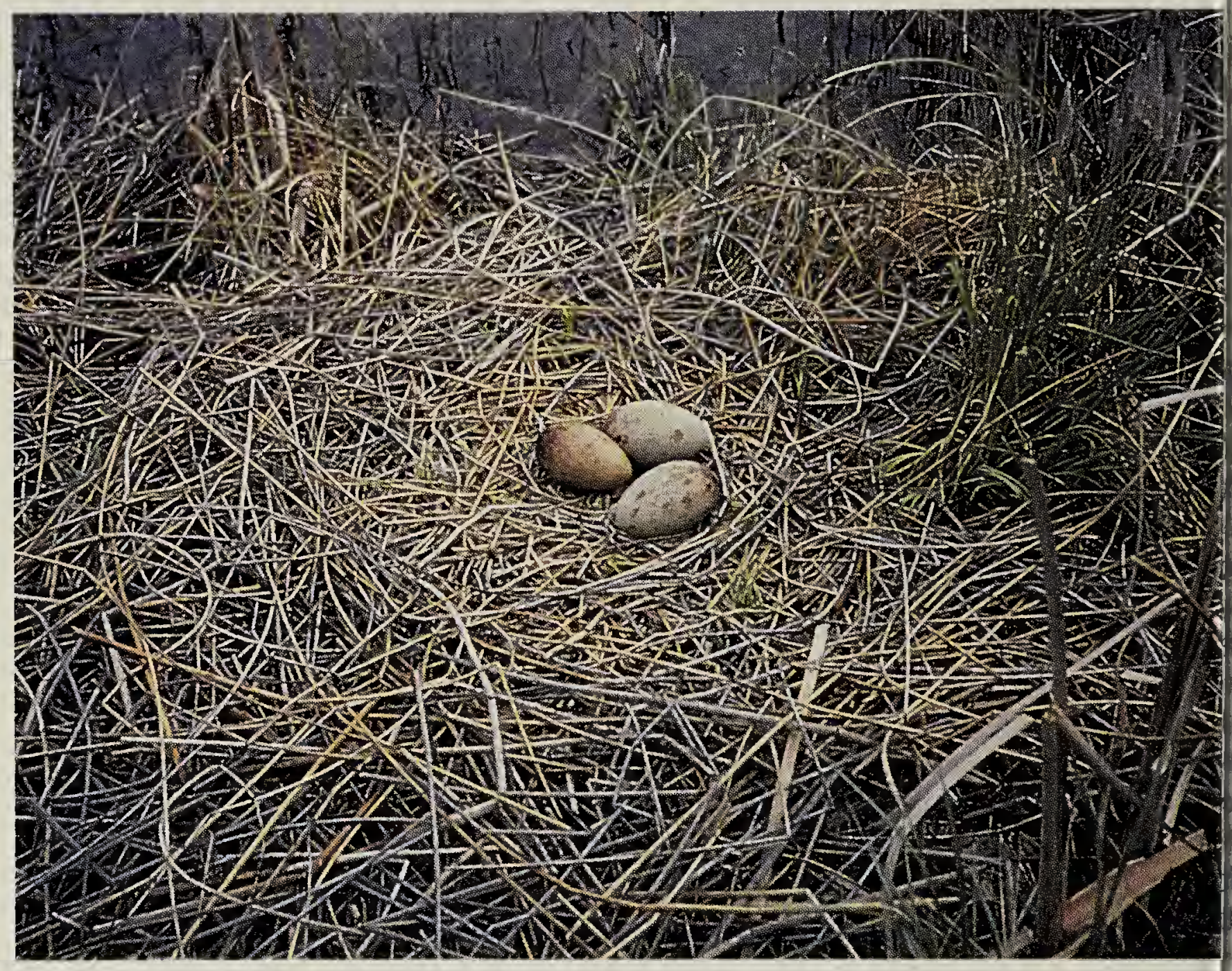

Figure 1. Nest 21/88 containing two Whooping Crane eggs (right side) and si Sandhill Crane egg (left side of nest), 27 May 1988

Jacques Sa

ton, North Dakota and the bird, later determined to be a male, was taken into captivity where it eventually died of its injuries. The surviving adult and her juvenile White-Blue safely reached the winter range on the Aransas National Wildlife Refuge (ANWR).

Although female BWB-Red became associated with an adult male at ANWR that winter and apparently began spring migration with that bird, the male bred with an unbanded female in 1985 and I have little information on the summer location of BWB-Red. On 18 September Paul Goossen (pers. comm.) saw the female with her yearling White-Blue and an apparently unbanded crane just east of a shallow reference lake, called Whale Lake, about $450 \mathrm{~m}$ south of the eventual nest $21 / 88$. It is highly unlikely that BWB-Red nested in 1985 and she spent the winter at ANWR with sub- adults (Tom Stehn, pers. comm. though it is possible that the unbar crane may have been with her.

I did not locate BWB-Red in 198 obviously she had nested somewl for when she arrived at ANWR in 1986 she was accompanied by ar banded chick and an unbanded a Sometime in the autumn of 1986 female's colour bands disappearer the bird, still carrying a metal band on the left leg, became difficult to $i$ tify.

In 1987 additional information obtained about BWB-Red. On $7 \mathrm{~N}$ found a Whooping Crane on a nest island in a $150 \mathrm{~m}$ long and wide oval lake, about $200 \mathrm{~m}$ nor Whale Lake. As the survey air flying at $300-350 \mathrm{~m}$, circled the (nest 27/87) the bird stood up (reve 
vo eggs in the nest) and moved into a and of spruce trees beside the nest ond. It is unusual for a Whooping rane to leave the nest when the aircraft at that altitude and the crane's beviour as well as the presence of a pair feeding Whooping Cranes only 300 from the nest may have been indicare of a relatively inexperienced breed$g$ pair at nest $27 / 87$. Two subsequent rial surveys at $300 \mathrm{~m}$ altitude conmed the skittish nature of the incubatg bird which would stand up at our proach, walk into the same clump of ruce trees and remain standing a few etres from the nest until the aircraft Id left. The bird's mate was observed all three occasions, first about $100 \mathrm{~m}$ im the nest, and $10 \mathrm{~m}$ from the nest the latter two occasions. Because of bird's behaviour and a concern that crane might abandon its nest I cided not to disturb the incubating rd again and not to collect an egg ring the 1987 egg pickup.

Our next survey, on 16 June, revealed at both eggs had hatched as the rents, feeding on the west shore of hale Lake, were accompanied by two pall chicks. Our 30 July survey indited one of the chicks had disappeared t the surviving chick was captured d colour-banded on 8 August. The mily group arrived at ANWR that fall d Tom Stehn (pers. comm.) observed e female's metal band and indicated at, also based on his knowledge of hooping Crane winter territories, the nale was the former BWB-Red.

Aerial surveys on 29 April and 3 May 88 revealed no whooping Cranes ar the previous year's nest $27 / 87$ but 5 May we sighted a pair of WhoopCranes on the ground $250 \mathrm{~m}$ east of hale Lake and nearby a flying Sandhill ane. We saw no colour bands on the hooping Cranes. The two birds ped in the air several times as the craft circled.
On 8 May a Whooping Crane was found on a nest (nest 21/88) on the same islet as in 1987. A second bird was seen $100 \mathrm{~m}$ south of the nest. As we circled the nest in order to plot its location on an airphoto, the crane got up from its nest and walked slowly into the woods east of the nest pond in exactly the same way as in 1987. There were two differently coloured eggs in the nest, one green and the other brown. Whooping Crane eggs when observed from the survey aircraft usually appear greenish in colour, and the light olive-green to buffy-green base colour with numerous brown or purplish-brown blotches can only be seen at closer range. There is considerable variation in egg colour: some are dark olive-brown eggs and in two cases (same pair in consecutive years) eggs were nearly white. In all cases where differently coloured eggs occurred in the same nest, there was never any doubt that both eggs were Whooping Crane eggs. Field reports for 1984 and 1987 do not make mention of differently coloured eggs in nests 26/84 and $27 / 87$.

On 10 May 1988 we circled nest $21 / 88$ to determine if the birds at the nest were banded. The incubating bird refused to rise and we saw no bands on the second bird nearby. On 16 May the incubating bird did not leave the nest as we approached. Its behaviour now was similar to that of other nesting cranes and I decided to include nest 21/88 in the nests earmarked for removal of surplus eggs.

When I approached the small nest island during the egg pickup on 27 May I noted a clutch of three eggs in the nest (Fig. 1), two eggs of normal greenish colour, the third egg a glossy lightbrown colour. My 1988 report on egg removal states the brown egg resembled that of a Sandhill Crane. All three eggs were tested in the field, were alive and were judged to be between 15 


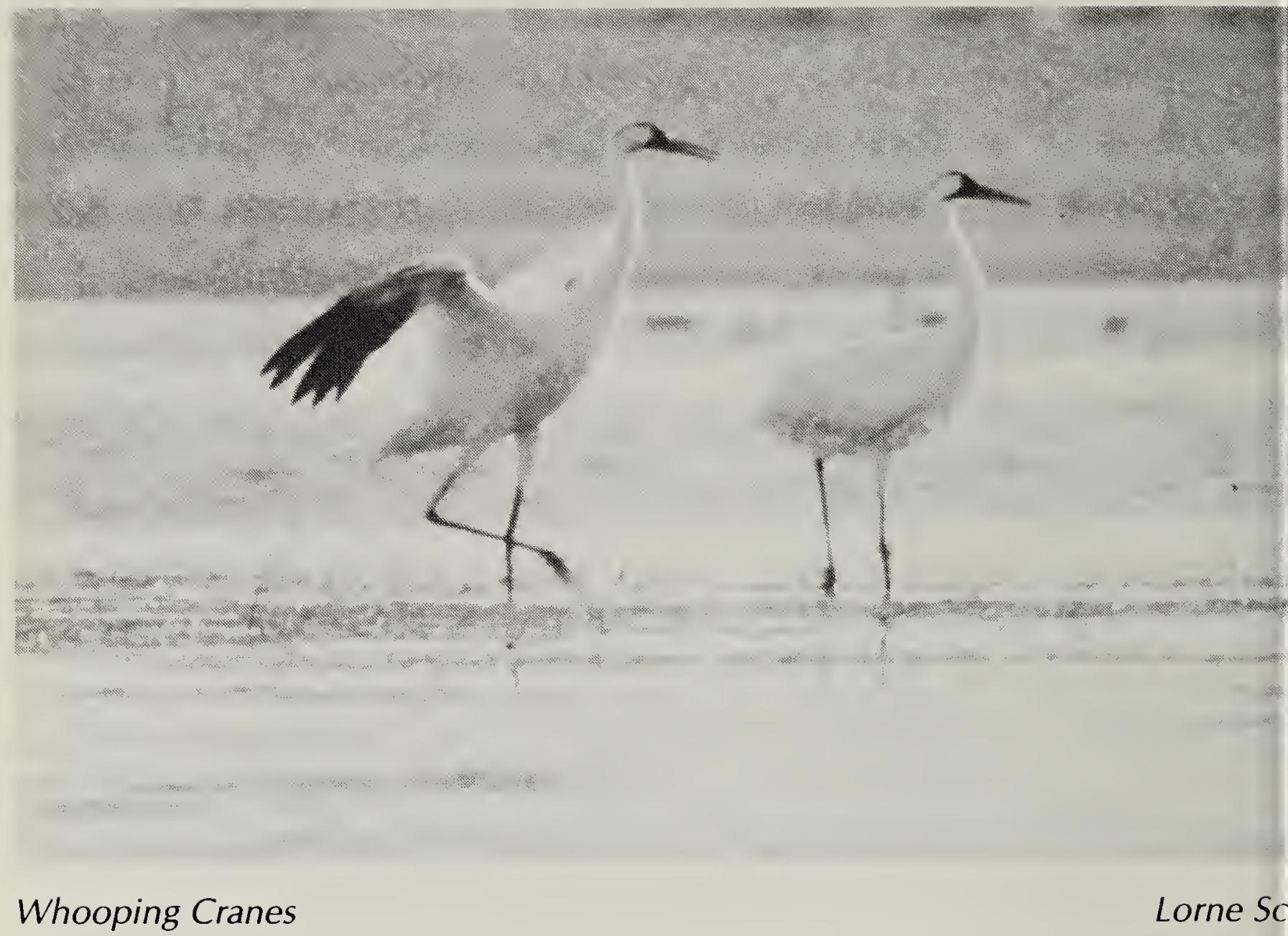

and 22 days old. Whooping Crane eggs in this category when suspended in water, have the air-cell end of the egg just touching the water surface or protruding slightly above it. One of the two green eggs was the youngest egg in the clutch and the other two eggs were approximately the same age. The older of the two green eggs was left in the nest. Measurements of the collected green and brown eggs (length, width, weight) were respectively $102 \mathrm{~mm}, 62$ $\mathrm{mm}, 198 \mathrm{~g}$ and $96 \mathrm{~mm}, 61 \mathrm{~mm}, 169 \mathrm{~g}$. One live Whooping Crane egg removed from nest 18/88 in 1988 was smaller in all three measurements than the egg we believed to be a Sandhill Crane egg. The second egg in nest 18/88 was thinner and weighed less than the Sandhill Crane egg but all other Whooping Crane egg measurements in 1988 were greater than those of the Sandhill Crane egg.

Both eggs, shipped to the Patuxent Research Center, U.S. Fish and Wildlife
Service, Laurel, Maryland, hatched, brown egg on 5 June, the green one 8 June (Dave Ellis, pers. comm.). Da Ellis also confirmed that the chi hatched from the brown egg was Sandhill Crane.

\section{Discussion}

The younger of the two Whoopi Crane eggs from nest $21 / 88$ which $n$ shipped to the Patuxent Research $\mathrm{C}_{\epsilon}$ ter, hatched there on 8 June and con quently was laid on or about 9 May. T Sandhill Crane from nest $21 / 88$ hatch at Patuxent on 5 June and, with a 2 30 day incubation period, would ha been laid on or about 6 May. ${ }^{\circ}$ Whor ing Crane eggs are usually laid two di apart and although the hatching date the egg left in nest $21 / 88$ is not know hatching would have occurred on about 6 June and the Whooping Cra eggs likely were laid on 7 and $9 \mathrm{Ma}$

The most plausible scenario leadi up to the mixed clutch of eggs sugge 
at the Sandhill Crane laid her egg on May during the Whooping Crane air's absence. When the Whooping rane female went to the nest to lay her $\mathrm{g} g$, she and her mate could easily have iven off the Sandhill Crane, reocupied the nest and continued the noral defense of the nesting territory. hooping Cranes introduced in Grays ke, Idaho, frequently have been obrved driving off Greater Sandhill anes and there seems to be no reason hy the smaller Sandhill Crane subecies in WBNP could not also be icted by Whooping Cranes.

It does not take Whooping Cranes ng to begin egg laying after the cometion of spring migration. On 5 May 388 I observed family $21 / 87$ (includ$\mathrm{g}$ its colour banded juvenile, then out 11 months old) near the Sass river out $12 \mathrm{~km}$ east of its previous year's st. Three days later the adults had an $\mathrm{g}$ in a nest in the same small nest pond here they have nested each year since 84. In this short interval, the cranes mpleted their migration, spent some ne near the Sass river, flew to their eeding territory, prepared the nest d produced an egg. It is therefore ite possible that the pair of Whoopg Cranes we observed east of Whale ke on 5 May 1988 could have had a mpleted nest and an egg on 8 May.

$t$ is also possible, but less likely, that Whooping Crane egg was the first $e$ in the nest and that that crane temrarily left the nest area allowing the ndhill Crane to move in and lay an g. In my experience, Whooping anes almost never leave their nest d egg(s) for long and, with both adults ernating incubation duties, one bird always on or at the nest. Walkinshaw o reports on the attentiveness of ines at nests.' It is not known if ung, inexperienced cranes are less entive than older birds at nests, but in $w$ of an observed lower hatching success at nests of first-time breeding Whooping Cranes (Ernie Kuyt, unpubl. data), I consider this a possibility. Numbers of Whooping Cranes in the WBNP population have increased in recent years. ' We do not have population data for Sandhill Cranes in the area, but if the latter bird's population increased or remained the same, the potential number of interactions between the two species would increase. Each spring since 1981 single Sandhill Crane nests (two nests in 1983) were found fortuitously during aerial surveys for Whooping Cranes. Sandhill Cranes in WBNP, feeding or on nests are more difficult to sight than Whooping Cranes, and Sandhill Cranes no doubt are more common than our records indicate. Although both species will nest in similar habitat there is a greater proclivity for Sandhill Cranes to nest on small natural islets or hummocks in shallow ponds, and their nests, when viewed from the air contain smaller amounts of nest material than the often bulky nests of Whooping Cranes. Of nine Sandhill Cranes nests found since 1981 during Whooping Crane breeding pair surveys, one nest was found as close as $350 \mathrm{~m}$ from the nest of a second-time nesting pair of Whooping Cranes. None of the other eight nests were closer than 750 $\mathrm{m}$ to the nearest Whooping Crane nest.

The two species may approach each other closely during the nonbreeding portion of their stay in WBNP: we have observed subadult Whooping Cranes feeding with Sandhill Cranes on a few occasions and during banding in 1987, Jonathan Kuyt carrying a just captured Whooping Crane chick to the helicopter, flushed a flightless juvenile Sandhill Crane from a small hummocky island. That chick (also captured and banded) was close to attaining flight as judged by the development of primaries and much closer to flight stage than the Whooping Crane chick captured nearby. 
Three-egg clutches in Whooping Cranes are exceedingly rare and only three clutches in 406 observed nests between 1966 and 1988 contained three eggs each. ${ }^{1}$ None of the nine eggs hatched and the only hatching success of one or more eggs in a three-egg Whooping Crane clutch is mentioned by Bradshaw from a marsh near the village of Plenty, Saskatchewan in what may have been the last nest recorded in Saskatchewan. ${ }^{2}$

Blue Goose dump nests and nest parasitism involving Blue Geese and other birds are not uncommon in the vicinity of dense nesting colonies in arctic areas, particularly in late seasons with delayed snow melt. ${ }^{9}$ It is unlikely that any of the chicks hatched from foreign eggs in nests involving interspecific nest parasitism as described by Prevett would have survived for long. In the case of Sandhill-Whooping Crane mixed clutches, chances of survival of these closely related species would be greater than in the above arctic examples. The present record indicates that Whooping Cranes are capable of incubating a three-egg clutch of eggs without loss up to the third week in incubation. I consider it likely that all three eggs would eventually have hatched if left undisturbed. Survival to flight stage of all three chicks would have been considerably less certain.

\section{Acknowledgements}

I thank Alex Dzubin (CWS) for providing useful references, Roger Edwards (CWS) for reviewing the paper, Jacques Saquet (Canadian Parks Service) for use of the nest photograph and Jim Carpenter, Patuxent Research Center, U.S. Fish and Wildlife Service for providing hatching data of eggs.

1 BENT, A.C. 1927. Life histories of North American marsh birds. United States National Museum Bulletin 135 (Dover Reprint 1963). $392 \mathrm{pp}$.
2 BRADSHAW, F.1956. The home of th whooping crane. Blue Jay 14(3):76-78.

3 KUYT, E. 1976. Recent clutch size data f whooping cranes, including a three-e: clutch. Blue Jay 34(2):82-83.

4 KUYT, E. 1976. Whooping Cranes: The lor road back. Nature Canada 5(2):2-9.

5 KUYT, E. 1979. Banding of juvenile whoo ing cranes and discovery of the summ habitat used by nonbreeders. Pp. 109-111 Proceedings 1978 Crane Worksho Rockport, Texas. Edited by J.C. Lewis. Ca orado State University Printing Service.

6 KUYT,E. 1981. Clutch size, hatching succes and survival of whooping crane chicks, Wor Buffalo National Park, Canada. Pp. 126-12 in Proceedings International Crane Syr posium, Sapporo, Japan. Edited by J.C. Lew and $\mathrm{H}$. Masatomi. International Crane Fou dation, Baraboo, Wisconsin.

7 KUYT, E. 1988. Whooping Cranes in 198 another year of progress. Blue 1 46(3):136-138.

8 KUYT, E. and J.P. GOOSSEN 1987. Surviva age composition, sex ratio and age at fir breeding of Whooping Cranes in Wood B falo National Park, Canada. Pp. 230-244 Proceedings 1985 Crane Workshop, Grar Island, Nebraska. Edited by J.C. Lewis. Plat River Whooping Crane Maintenance Tru Grand Island, Nebraska.

9 PREVETT, J.P., B.C. LIEFF and C.D. MACI NES 1972. Nest parasitism at McConne River, NWT. Can. Field-Nat. 86(4):369-37

10 WALKINSHAW, L.H. 1949. The Sandh Cranes. Bulletin No. 29. Cranbrook Instit। of Science, Bloomfield Hills, Michigan. 2 pp.

11 WALKINSHAW, L.H. 1965. Attentiveness cranes at their nests. Auk 82:465-476. 